\title{
THE IMPACT OF TRADE CREDIT INVESTMENT ON MANUFACTURING FIRMS' PROFITABILITY: EVIDENCE FROM VIETNAM
}

\author{
Duong Phuong Thao Pham¹, Thi Cam Ha Huynh ${ }^{1}$ \\ ${ }^{1}$ School of Finance, University of Economics Ho Chi Minh City, 59C Nguyen Dinh Chieu, Ward 6, District 3, Ho Chi \\ Minh City, Vietnam
}

Link to this article: https://doi.org/10.11118/actaun202068040775

Received: 18. 3. 2020, Accepted: 6. 8. 2020

To cite this article: PHAM DUONG PHUONG THAO, HUYNH THI CAM HA. 2020. The Impact of Trade Credit Investment on Manufacturing Firms' Profitability: Evidence from Vietnam. Acta Universitatis Agriculturae et Silviculturae Mendelianae Brunensis, 68(4): 775-796.

\begin{abstract}
The aim of this study is to examine the effect that trade credit investment has on firms' profitability. The characteristics of this relationship have not been dealt with in depth for manufacturing firms. We use panel data for a total of 227 Vietnamese publicly listed manufacturing firms for the period 2005-2017. Different econometric estimation techniques such as the feasible generalized least squares, fixed effects and random effects and different calculation of firm performance such as non market-based measure (return on assets) and market-based measure (Tobin's q) are employed to validate the consistent results. The robust results confirm a statistically significant inverted U-shaped relationship between trade credit investment and profitability.
\end{abstract}

Keywords: trade credit investment, profitability, manufacturing firms

\section{INTRODUCTION}

Since working capital management has always been a big concern, much attention has been drawn to this field in recent decades (Chen and Kieschnick, 2018; Pirttilä et al., 2019; Jędrzejczak-Gas, 2017; Dhole, Mishra and Pal, 2019). It is proved that working capital policy can affect the efficiency of the firm's operation, which impacts on the possibility of gaining profit (Deloof, 2003). This continually raised the question of how each component in working capital drives profitability, which would be an interesting topic for many scholars (Mun and Jang, 2015; Kestens, Van Cauwenberge and Bauwhede, 2012). Since trade credit takes an important role in a firm's operation as an incorporated channel of credit, previous works have concerned the relationship between trade credit and profitability. With firms providing its customers a delay for payment, they expect to receive an extra value as an interest by the time of payment. This fact makes trade credit become a short term investment. Moreover, supplying trade credit is also a tool to enhance sales and increase competitive advantage. In general, the act of supplying trade credit has the possibility to be related to firm profitability or firm performance. Unlike the period of the 1960s when trade credit received little attention, there has been a rapid rise in the amount of works conducted in this field. A significant number of researches have been done analyzing how firm profitability determines the trade credit extension (Demirgüç-Kunt and Maksimovic, 2001; Alarcón, 2011; De Carvalho and Schiozer, 2015; Kim, 2016) and the adverse effect (Martínez-Sola, García-Teruel and Martínez-Solano, 2014; Box et al., 2018; Zhu and Jiang, 2009; Paul, Devi and Teh, 2012). However, there has been little discussion on these relationships in a particular industry. Most studies have only focused on the impact of trade credit upon profitability across the industries (Kestens, Van Cauwenberge and Bauwhede, 2012; Abuhommous, 2017). On the 
other hand, the empirical results are mixed. Some researches in the later years stated that the relationship between trade credit and firm performance is linear (Martínez-Sola, García-Teruel and Martínez-Solano, 2014) but more works in recent years suggested that trade credit could have the U-shaped effect on the firm's profitability (Afrifa, 2016). It is also shown that this relationship could be positive (Abuhommous, 2017) or negative (Zhu and Jiang, 2009). This issue not only stays unclear in developing economies but also in emerging economies due to the limitation of works. To fill in this gap of previous literature and strengthen the evidence, we discuss the U-shape relationship between trade credit and firm profitability within emerging economies represented by Vietnam.

In order to investigate the above relationship, we use a panel of Vietnam listed manufacturing firms for the period 2005-2017. Our sample includes 1,666 firm-year observations collected from the stock exchange market in Vietnam. More than 99\% of firms spend about 18\% of their total assets on investing in trade credit. Moreover, this study is designed to apply the methodology developed by Dary and James (2019) so as to examine the effect of trade credit on firm performance. In which, the statistical models consist of Feasible generalized least squares (FGLS), Fixed-Effect Model (FEM) and Random-Effect Model (REM). In terms of variables, we define profitability to be the earnings before interest and tax (EBIT) over the total asset signed as ROA which is the dependent variable. The main explanatory variable is trade credit calculated as trade receivables divided by the total asset denoted as RECA. Besides, firm size, liquidity, competitive scope, growth opportunities, leverage and GDP are other factors that affect ROA ratio. The findings show that the trade credit investment has a significantly positive impact on the firm's performance.

We also run instrumental variable (IV) fixed effects so as to solve the endogeneity problem in our regression model. While trade credit investment may promote profitability, there is an argument that thanks to the abundant resources, firms are able to expand their credit policies. The IV estimation not only provides the evidence of the absence of endogeneity in our models but also supports previous results.

For robust check, Tobin's q is used as an alternative indicator of firm's performance. The difference is that Tobin's $q$ measures the value of a firm by considering the market value of equity. In other words, it is based on the evaluation of the market about firm performance. In this case, we found that the result is consistent with our initial findings.

The quadratic of trade credit is also added (RECA2) to models to test the U-shaped relationship between trade credit and firm profitability. Applying the Sasabuchi-Lind-Mehlum approach, we find that there is a nonlinear relationship between these two variables. That means if the trade credit investment exceeds a certain point, the profitability will decrease. This relationship is shown to be robust in all models.

\section{Literature Review and Hypothesis Development}

In this field, a significant number of studies using different methods have been conducted and produced variant results. In the early years of $21^{\text {th }}$ century, Deloof (2003) finds that the relationship between trade credit, specifically receivable, and firm profitability is negative when testing how working capital management impacts on the firm performance using the data of more than 1,000 big firms during the time of 1992-1996 in Belgium. The outcome of this work is claimed to be different from that of later studies, which is explained as the discrepancy of the measurers in estimating trade credit receivable and the number of days of accounts receivable. Hence, the caution should be taken into consideration in compare the results with those of literatures using traditional trade credit measure. The role of trade credit during economic recession has gained wide attention after the event in 2008. In Belgium, Kestens, Van Cauwenberge and Bauwhede, (2012) studies the effect of investing in trade credit on firm profitability during the financial crisis in 2008 among non-financial firms and finds that the more investment a firm puts in trade credit, the more reduction the adverse impact of crisis on the performance of the firm makes. Later years, McGuinness, Hogan and Powell (2018) conducts a research on trade credit use and SME survival through the period of 2008 and its result is consistent with the one of early works. This paper shows the confirmation of the positive impact of trade credit on firm survival, especially during the years of the financial crisis in Europe. This result also proves the vital role of trade credit as a channel of financing for the life of a business. Recent work of Grau and Reig (2018) has showed an unclear result for the impact trade credit has on firm profitability during the financial crisis in Europe. With the approach of differentiating the policies and customs with respect to the granting of trade credit, the estimated effect has stated depending on country, size, specificity, market power and reputation. In the previous year (2014), this group of researchers also suggests that firms in Spanish agri-food industry should give more credit to their customers for more profits if the economy is stable and give less credit in the recession time. The association of trade credit and profit has been widely tested in the last ten years. Gofman (2013) proposes that if the firm which is upstream in the supply chain invested more in the trade credit, it would have higher profits. More recent proof, Abuhommous (2017) states that a firm with higher investment on trade credit would experience an increase in profit compared with the average 
industry investment in trade credit estimated on the figures of listed Jordania firms. More attempts have been made by Box et al. (2018) to expand the effect of trade credit on other indicators of firm profitability. Their research shows a further finding which indicates that the firm extending their trade credit would have a significantly higher margins, revenues and market share associated with their competitors with similar characteristics, operational necessities and distress level. Further understanding, this outcome implies that aggressive trade credit policy can provide an unique channel to improve the performance on product market for firm management. For the international result, the study carried by Demirgüç-Kunt and Maksimovic (2001) with the data from 39 countries of publiclytraded firms has given more statistical evidence of the positive relationship between receivable turnover and firm's profit.

As mixed as the impact of trade credit on firm profitability, the tests on their linear relationship also give confusion. The study of Martínez-Sola, García-Teruel and Martínez-Solano (2014) using FEM, REM and IV estimations on the panel data of 11,000 Spanish SMEs shows the linear and positive relationship between trade credit and firm profitability. Another study in 2014, however, indicates a convex relationship between trade credit investment and wholesale firms in Denmark, Norway and Sweden. This work is conducted by Lorenz (2014) using the balance of account receivable to measure the trade credit. The author concludes that the firms with shorter days of receivables outstanding tend to have a decrease in profit and vice versa. Beside these types of relationship, U-shaped has also been confirmed as a type of relationship between trade credit and firm performance. Asimakopoulos, Da and Fernandes (2017) examine the impact and believe that trade credit and firm profitability have the U-shaped relationship implying the negative effect on firm performance when firm is at the low level of trade credit and the positive effect when firm is at higher level of trade credit among Europe firms. Recently, Afrifa (2016) also finds the U-shaped relationship between net trade credit investment (receivable outstanding minus payable outstanding) and firm profitability estimated by ROA and Tobin'q in the UK with figures of SMEs.

In recent years, Vietnam is expected to be an alternative manufacturing centre in Asia due to the US - China trade war. Furthermore, in Vietnam, the structure of the manufacturing industry has been changing over time, towards industrialization and modernization. In the publication named Doing business in Vietnam 2019, PwC records that the value of exported high-tech products is roughly 43 billion dollars which is higher than Thailand ( $\$ 34$ billion), Philippines ( $\$ 32$ billion) and Indonesia (\$3.9 billion) in 2016. PwC also points out five advantages that make Vietnam become the next destination for manufacturers. Firstly, Vietnam is considered as an emerging manufacturing export country with the total export value was approximately 244.7 billion dollars in 2018, up $13.8 \%$ against 2017 . Secondly, revenue of products with high value increased during the 2013-2018 period, the growth increased from $18 \%$ to $26 \%$. Thirdly, Vietnamese market has strong demand for manufactured goods. Although frequently fluctuating in 2019, the Purchasing Managers' Index (PMI) of greater than 50 proved the manufacturing industry has been expanding and had positive transformations. Fourthly, Vietnam is considered as the best alternative for international manufacturing corporations to avoid influences of the trade war. Finally, during the period of 2012-2016, the sustained high rate of infrastructure investment encourages the development of manufacturing operations.

Vietnamese researchers have conducted a lot of studies in the subject of profitability of a firm for a long time. Indeed, in recent years, there has been growing interest in this issue. For example, Tran, Abbott and Jin Yap (2017) investigated the impact of working capital management on the profitability of Vietnamese small and medium sized enterprises (SME). Analyzing the data of 200 manufacturing SMEs listed on the Hanoi Stock Exchange, they underlined that the optimal working capital management will maximize the profitability of a firm. By contrast, poor working capital management is one of the main reasons that make the business fail. More recent evidence, Nguyen, Tran and Do (2018) examined the relationship between types of government support and profitability of SMEs in Vietnam. By using the fixed-effect quantile regression method, they claimed that the government financial support has a negative impact on the SMEs profitability in low quantile, but positive with the high one. Additionally, financially supporting policies of the government can be effective since they may help the firm improve the growth in profitability. Many attempts have been made, Vu et al. (2019), in order to find out determinants of Vietnamese listed firm performance such as competition, wage, CEO, firm size, age and international trade. In brief, the profitability of firms always receives the attention of scholars.

On the contrary, trade credit is not as popular as the profitability in Vietnam. However, Uyen (2012) investigates the relationship between trade credit and sales growth, firm competitiveness, customer characteristics, market segments. The findings show that suppliers are willing to provide more credit to larger and/or bargaining power and/or creditworthy clients. In addition, trade credit has a positive relation with firm sales growth. In other words, trade credit works as a marketing device to promote sales. 
In general, all studies listed above still has some limitations. Data are out of date. Hien Tran uses the data from 2010 to 2012 while Vu et al. (2019) conducts the research on a sample obtained in 2015. In addition, Uyen (2012) claims that the data collected may be biased. Besides, research on the impact of trade credit on profitability of firms is still limited in emerging economies, especially in Vietnam. Thus, this paper is expected to provide more empirical evidence for this association.

There remains a controversy surrounding the association between trade credit investment and firm profitability. The relationship between receivable turnover and firms' profit has been found to be positive (Demirgüç-Kunt and Maksimovic, 2001). Martínez-Sola, García-Teruel and MartínezSolano (2013) affirm the positive linear relationship between trade credit and firm profitability by using data of 11,000 Spanish SMEs. More recent evidence (McGuinness, Hogan and Powell, 2018; Abuhommous, 2017; Box et al., 2018) appears to support previous findings. However, a negative relationship has been stated in other studies. Grau and Reig (2014) concluded that in financial crises, the increase in trade credit investment can lead to a decrease in firms' efficiency and profitability. Even though this result differs from some published studies, it is similar to Deloof (2003). Notably, the U-shaped relationship between trade credit investment and profitability has been found in many studies (Lorenz, 2014; Afrifa, 2016; Asimakopoulos, Da and Fernandes, 2017).

The explanation for the positive relationship can be attributed to financing theory, transaction cost theory and commercial theory. Previous works in the context of financing theory have shown that firms may offer trade credit to customers to increase sales and profits when the cost to raise funds from financial markets is high due to tight monetary policy (Meltzer, 1960). Emery (1984) suggests that firms with surplus liquidity can invest in either marketable securities or trade credit to earn interest income, thus generating additional returns and earn more profits. Based on transaction cost theories, Emery (1984) claims that firms using trade credit can yield higher profits by economizing on transaction costs. Furthermore, in times of low demand, firms can extend trade credit to stimulate the volume of transactions, thus leading to performance and efficiency improvement. Several studies (Schwartz, 1974; Ferris, 1981; Emery, 1984) have been carried out and implied that inventory carrying cost as well as a number of bank transactions and the associated costs deduct as firms decided to supply trade credit. From the commercial point of view, trade credit investment can be used as a tool to expand firms' brands. Many attempts have been made (Nadiri, 1969; Wilner, 2000; Cheng and Pike, 2003) in order to point out that trade credit helps sellers to increase sales and profits due to competitiveness enhancement.
As supply firms gain more market share by using the competitive selling policy, they yield better income (Nadiri, 1969; Wilner, 2000) or firms having differentiated credit products to customers also have the same results (Cheng and Pike, 2003). Moreover, long-term commercial relationships have been developed which keep customers loyal, thus leading to a steady demand for firms' products (Long, Malitz and Ravid, 1993; Ng, Smith and Smith, 1999; Wilner, 2000; Cheng and Pike, 2003). Smith (1987) suggests that sellers must establish a reputation for product quality and use trade credit as a means of generating repeat sales; it is an investment by the seller to get the buyer's sales, as well as a means of generating information on the buyers' default risk. Long, Malitz and Ravid (1993) further consistently affirms that trade credit can be used as a means by which sellers can guarantee quality to buyers and ensure repeat sales.

Nonetheless, the negative relationship between trade credit investment and firm profitability appears when the costs arising from the investment exceed the economic benefits. When firms remain receivables, they have to incur administrative costs such as monitoring costs, enforcement costs and the cost to manage accounts receivable (Nadiri, 1969; Ng, Smith and Smith, 1999; Martínez-Sola, García-Teruel and Martínez-Solano, 2013; 2014). Nadiri (1969) also claims that the main financial risks involved in credit trade investment consist of delayed payment, default risk and the opportunity cost of credit sales instead of cash sales. If the costs overstep the benefits, idle funds spent in trade credit investment rather than other investments deteriorate firms' profitability as a result (Cheng and Pike, 2003; Martínez-Sola, García-Teruel and Martínez-Solano, 2014). Therefore, Nadiri (1969) and Emery (1984) both suggest that firms should find out the optimal point where the costs and benefits are equal.

Furthermore, prior studies question the difference in the relationship between trade credit and profitability among industries (Dary and James, 2019, Grau and Reig (2018), Mun and Jang (2015)). Grau and Reig (2018) examine this relationship in the European agro-food firms and confirm that the impact of trade credit on profitability depends on firm size. In other words, larger companies will be more profitable if they grant more trade credit investment. Additionally, there is a difference in the effect of trade credit on profitability among different industries. A recent research (Dary and James, 2019) finds a positive linear relationship between trade credit investment and firm profitability in the U.S. agro-food industry. Meanwhile, in the restaurant industry, Mun and Jang (2015) reveals firms' working capital which includes accounts receivable has a significant inverted U-shaped relationship with profitability. The above-mentioned relationship in individual industries have caught much scholar's attention for decades (Dary and James, 2019; Grau 
and Reig, 2018; Mun and Jang, 2015). However, few researchers have addressed the issue in the manufacturing industry. The aim of our work was thus to contribute to the depth understanding of the relationship between trade credit and profitability with the case of Vietnam.

Trade credit is a contract that allows firms to buy goods without making immediate payment. It is well recognized as a very expensive source of credit. However, many small firms hardly access bank loans due to many reasons, and thus taking trade credit from suppliers instead. Suppliers may have advantages over banks in evaluating and controlling credit risk because of closer interaction with buyers. A unique characteristic of the manufacturing industry is that the inventory is mainly raw materials. When the economic conditions are good, manufacturing suppliers can grant much more trade credit investment to sell more goods compared to the service industry. If the goods supplied cannot be resold by the buyers, the suppliers could easily stop the trade credit policies or even repossess the good and resell to other buyers in case of default. Another reason to explain the existence of high trade credit in manufacturing firms is the source of funds. Generally, firms in the manufacturing industry heavily invest in tangible assets, thus having higher liquidation value, having better access to debt financing (Van der Wijst and Thurik, 1993; Jordan, Lowe and Taylor, 1998). la Rocca, la Rocca and Cariola (2010) show evidence that manufacturing firms use higher bank loans and obtain long-term debt more easily, due to the lower levels of information asymmetry. Since trade credit is a short term investment, manufacturing firms can finance it with long term debt in order to have less liquidity risks. Because of described benefits, trade credit investment may have a positive effect on manufacturing firms' profitability. As for agrofood firms, Dary and James (2019) claim a positive linear relationship. However, investment in trade credit in this industry is considered to be lower than non-food industries such as manufacturing industry (Fafchamps, Pender and Robinson, 1995; Martínez-Sola, García-Teruel and MartínezSolano, 2014). Since the amount of accounts receivable in the manufacturing industry is high, it is harder to manage all the risks associated with the credit policies. There may be a point where the relationship between trade credit investment and profitability is negative. At the beginning, trade credit investment increases manufacturing firms' revenues. However, the working capital would be tied in the trade credit investment, thus increasing the cost of equity. Besides, the more the firms invest in the trade credit, the higher the administrative costs increase. Therefore, we expect that in Vietnam, the relationship between trade credit investment and manufacturing firms' profitability is inverted U-shaped.
Many attempts have been recently made in order to point out determinants of Vietnamese firms' profitability. These factors can be specified as working capital management (Tran, Abbott and Jin Yap, 2017), firm size (Vu et al., 2019). Besides, Uyen (2012) states a positive relationship between trade credit and sales growth. Previous studies indirectly propose a possibility that trade credit of Vietnamese manufacturing firms affect profitability. With the above arguments, we thus expect our main hypothesis expressed as:

Hypothesis: Trade credit investment and profitability of Vietnamese manufacturing firms have an inverted U-shaped relationship.

\section{MATERIALS AND METHODS}

\section{Data Collection}

This study uses financial data and macroeconomic indicators obtained from the Vietnam stock exchanges and World Bank.

Our initial sample includes manufacturing firms whose shares are listed on the Vietnamese stock exchanges over the period 2005-2017. To ensure the comparability between firms, we restrict the sample to firms with years ending in December. The database surrounds firms with the following Industry Classification Benchmark (ICB) codes: 1000 (Basic materials), 2000 (Industrials), 3000 (Consumer discretionary), 4000 (Health services), 5000 (Consumer service), 7000 (Infrastructure services). Telecommunications (ICB 6000), Financial (ICB 8000), Technology (ICB 9000) are excluded from the sample since we focus on manufacturing firms. Furthermore, we drop Nonmetallic Mineral Product firms from our sample because these firms have an abnormal turnover unlike other firms. The final sample is made up of 227 firms, with a total of 1,666 firm-year observations for the period 2005-2017.

\section{Measure Main Variable}

The dependent variable of this study is ROA, it is on behalf of the firm profitability. Following previous investigations, ROA is the best indicator of firm profitability or firm performance. (e.g., Maury, 2006; Zhu and Jiang, 2009; Martínez-Sola, García-Teruel and Martínez-Solano, 2014; Li et al., 2016; Tang, 2014; Deloof, 2003; Grau and Reig, 2015; Kim, 2016). $\mathrm{ROA}$ is defined as the ratio of earnings before interest and taxes (EBIT) to total assets (Martínez-Sola, GarcíaTeruel and Martínez-Solano, 2014; Kim, 2016).

The main explanatory variables are trade credit investment (RECA) and the square of trade credit investment (RECA2). RECA is expressed as the ratio of trade receivable to total assets. The measurements of trade credit investment have been utilized in prior papers. (e.g., Deloof and Jegers, 1999; Zhu and Jiang, 2009; Kim, 2016; Alarcón, 2011; Kestens, Van Cauwenberge and Bauwhede, 2012; MartínezSola, García-Teruel and Martínez-Solano, 2014; 
I: Industry Classification

\begin{tabular}{lclc}
\hline \multicolumn{1}{c}{ Sector } & ICB code & \multicolumn{1}{c}{ Industry group } & Quantity \\
\hline \multirow{2}{*}{ 1000 - Basic materials } & 1750 & Furniture and Related Products & 6 \\
& 1730 & Wood Products & 4 \\
\hline \multirow{2}{*}{ 2000 - Industrials } & 2720 & Plastics and Rubber & 39 \\
& 2730 & Machinery Manufacturing & 24 \\
& 2750 & Transportation Equipment Manufacturing & 3 \\
\hline \multirow{3}{*}{3000 - Consumer discretionary } & 3570 & Food Manufacturing & 55 \\
& 3530 & Beverage - Tobacco & 12 \\
\hline \multirow{2}{*}{ 4000 - Health services } & 3720 & Apparel Manufacturing & 19 \\
\hline 5000 - Consumer service & 3760 & Textile Mills & 7 \\
\hline S0urce: Own processing according & 4530 & Miscellaneous Manufacturing & 5 \\
\hline
\end{tabular}

Source: Own processing according to Vietnam Stock Exchanges dataset

Muscettola, 2014). This ratio measures how much of total assets of a firm are used so as to invest in trade credit receivable. Besides, the square of trade credit investment (RECA2) is added to examine for nonlinear relationship between trade credit investment and firm profitability. RECA2 is mean centered to constrain collinearity.

\section{Measure Control Variables}

There are many firm-specific factors that can affect the firm profitability. This study considers the following control variables: firm size, liquidity, competitive scope, growth opportunities, leverage, economic growth,... In particular, firm size, liquidity (cash and short-term investment), leverage (debt), growth opportunities, and economic growth have been calculated from the literature as vital determinants of ROA.

Firm size (lnSize) is the natural logarithm of total assets Kestens, Van Cauwenberge and Bauwhede, (2012). Existing studies recorded various results for the relationship between firm size and firm profitability. For instance, the positive relationship has been found by Deloof (2003); Kestens, Van Cauwenberge and Bauwhede, (2012). In contrast, Goddard, Tavakoli and Wilson (2005) indicate the negative relationship between them and no relationship has been reported in the research of Martínez-Sola, García-Teruel and Martínez-Solano, (2014). For this study, we expect that firm size and firm profitability will be positively related because larger firms have been eligible to take advantage of profitable opportunities than smaller firms. In accordance with Goddard, Tavakoli and Wilson, (2005) larger firms may also enjoy economies of scale in production. The leverage (LEV), measured as total liabilities to total assets. It may enhance or constrain the firm profitability. The meaning of LEV is that firms that have a high leverage may find it difficult to access additional financial capital to take advantage of opportunities of profitability (Tsuruta, 2015); they can also have a loan at a higher cost owing to high riskiness. In this study, inverse relationship between leverage and firm profitability is expected. This negative relationship has been demonstrated in different papers. For example, Martínez-Sola, García-Teruel and Martínez-Solano (2014) in Spain, Tang (2014) in Netherlands, Abor (2007) in Ghana and South Africa, and Deloof (2003) in Belgian. On the contrary, Tsuruta (2015) states that leverage may enhance firm profitability through improving efficiency because of monitoring part of trade credit lenders.

Liquidity (lnLQD) is the natural logarithm of ratio of cash and short-term investment to total assets, predicted that firms with improved liquidity will experience more profits since they are better positioned to take advantage of profitable opportunities rather than raising external funds (e.g., Goddard, Tavakoli and Wilson, 2005; Kestens, Van Cauwenberge and Bauwhede, 2012). Goddard, Tavakoli and Wilson (2005) and Kestens, Van Cauwenberge and Bauwhede (2012) discovered firms with high liquidity and high profitability. Growth opportunities (Sgrowth) may affect positively on firm profitability. According to Deloof (2003), Martínez-Sola, García-Teruel and MartínezSolano (2014) and Li et al. (2016), sales growth is used as a proxy of Sgrowth. It is expected that high growth opportunities will enhance firm profitability, consistent with findings in other studies (e.g., Deloof, 2003; Martínez-Sola, García-Teruel and MartínezSolano, 2014). Based on prior study (MartínezSola, García-Teruel and Martínez-Solano, 2014), Variability in economic growth rates may reflect economic cycle. Hence, we include the yearly gross domestic income growth rate (GDP) of the Vietnam economy as the control variable in order to control 
for macroeconomic conditions that may impact on firm profitability. Higher economic growth rate is expected to result in more profits in firms. Finally, regional dummies (Southern, Northern, Central regions of Vietnam), time dummies (2005-2017) are included to control for location and time impacts. The variables and measurements are described below.

\section{Model Construction}

In this section, we focus the model construction to test the linearly positive relationship between trade credit investment and profitability of manufacturing firms. We use FGLS, fixed effects models (FEM) and random effects models (REM) to generate appropriate results based on panel data. These estimators are carried out as the pooled-OLS cannot effectively exploit economic information from our data. The pooled-OLS results obtained are unbiased but not effective since OLS skips autocorrelation and heteroscedasticity. Hence, Feasible Generalized Least Squares (FGLS) estimator should be used in this study so that it can control for autocorrelation and heteroscedasticity, offering effective estimators. Muthama Musau, Waititu and Wanjoya (2015) argues that GLS methods and robust Covariance Matrix Estimation should be regularly used in panel data analysis so as to guarantee the results drawn on such works not to be influenced by heteroscedasticity.

According to Wooldridge (2016), FEM allows arbitrary correlation between the idiosyncratic error and the explanatory variables across all time periods. Nonetheless, if the variables in the model are constant over time, they will be omitted. Therefore, if the value of the key explanatory variable is time-invariant values, we cannot use FEM to estimate its effect on the dependent variable. Also, the FEM results have not been specifically designed to the population (Greene, 2002). The fixed effects regression model is given by:

$$
\begin{aligned}
R O A_{i t}= & \beta_{0}+\beta_{1} R E C A_{i t}+\beta_{2} R E C A_{2 \mathrm{it}}+\beta_{3} \ln \operatorname{SIZE}_{i t}+ \\
& +\beta_{4} \ln L Q D_{i t}+\beta_{5} L E V_{i t}+\beta_{6} S_{\text {SROWTH }}+ \\
& +\beta_{7} G D P_{i t}+\lambda_{t}+\varepsilon_{i t} .
\end{aligned}
$$

Conversely, if there is not any correlation between idiosyncratic error and the explanatory variables in any time period, REM is more appropriate than FEM. Moreover, in REM, the time-invariant variables are not omitted so the result has not limited generalization to the population (Greene, 2002; Torres-reyna, 2007; Wooldridge, 2010). If our equation is controlled well, we can believe that any rest neglected heterogeneity only induces serial correlation in the composite error term, but it does not cause correlation between the composite errors and the explanatory variables. Notwithstanding, the random effects models do not control for omitted variables so the parameter estimates can be biased. The random effects regression model is given by:

$$
\begin{aligned}
R O A_{i t}= & \beta_{0}+\beta_{1} R E C A_{i t}+\beta_{2} R E C A_{2 i t}+\beta_{3} \ln \operatorname{SIZE}_{i t}+ \\
& +\beta_{4} \ln L Q D_{i t}+\beta_{5} L E V_{i t}+\beta_{6} S_{\text {SROWTH }}+ \\
& +\beta_{7} \text { COMPETIV }_{i t}+\beta_{8} G D P_{i t}+ \\
& +\tau_{s}+\eta_{l}+\lambda_{t}+\mu_{i t}+\varepsilon_{i t}
\end{aligned}
$$

Both FEM and REM have flaws, so their choice requires trade-offs (see Greene, 2002; Wooldridge, 2010) and Hausman test will help us solve this problem. The hypothesis HO of the Hausman test suggests that there is no correlation between the individual effect of each spatial crossover unit and other regression variables in the model. If the correlation occurs (HO is rejected), FEM is appropriate.

Besides, the study also executes some tests so that the results are more reliable. Breusch/Pagan test: this test is used to select between random effects models (REM) and pooled-OLS. The Breusch/Pagan specification method tests the null hypothesis that pooled-OLS is appropriate. Wald test: this test is used to test the heteroscedasticity in the model with the null hypothesis that the model has no heteroscedasticity. F test used to select the appropriate statistical model between pooled-OLS and FEM. The null hypothesis of the F test is that FEM surpasses pooled-OLS.

Furthermore, the endogeneity might occur between RECA and firm profitability (e.g., MartínezSola, García-Teruel and Martínez-Solano, 2014; Li et al., 2016), so the method of instrumental variables (IV) is indicated to solve this problem. Because the specification is dependent on the selection between FEM and REM mentioned previously. Finally, we use Sasabuchi-Lind-Mehlum test (see e.g., Dary and James, 2019) to test the linearly positive relationship between trade credit investment and profitability of manufacturing firms.

\section{RESULTS AND DISCUSSION}

\section{Descriptive Analysis}

We present descriptive statistics and correlation matrix in Tab. II and Tab. III, respectively. Since firms attempt to improve their performance in many ways, investing in trade credit became more popular in the period 2005-2017. In our sample, $99.94 \%$ of firms have trade credit accounts with $18.14 \%$ of their total assets, on average, being used to invest. Performance of companies, which is measured by return on assets ratio, shows an average number of $11.6 \%$ for each firm. None of the correlations between dependent variables presented in Tab. III is greater than 0.63. Moreover, Variance Inflation Factor (VIF) is less than 10. According to Hair, J. F. et al. (1995), not any clear signal of multicollinearity appears in this dataset. 
II: Descriptive Statistics

\begin{tabular}{|c|c|c|c|c|c|c|c|c|c|}
\hline Year & Stat & ROA & RECA & SIZE & LQD & LEV & Sgrowth & Competiv & GDP \\
\hline \multirow{5}{*}{2005} & Obs & 13 & 13 & 13 & 13 & 13 & 13 & 13 & 13 \\
\hline & Mean & 0.115 & 0.176 & 251,107 & 0.100 & 0.504 & 0.130 & 1.000 & 7.547 \\
\hline & Std.Dev. & 0.028 & 0.116 & 275,792 & 0.100 & 0.135 & 0.252 & 0.000 & 0.000 \\
\hline & Min & 0.077 & 0.013 & 35,038 & 0.005 & 0.328 & -0.194 & 1.000 & 7.547 \\
\hline & Max & 0.161 & 0.434 & 903,613 & 0.329 & 0.756 & 0.721 & 1.000 & 7.547 \\
\hline \multirow{5}{*}{2006} & Obs & 53 & 53 & 53 & 53 & 53 & 53 & 53 & 53 \\
\hline & Mean & 0.147 & 0.196 & 316,946 & 0.140 & 0.432 & 0.274 & 0.943 & 6.978 \\
\hline & Std.Dev. & 0.071 & 0.114 & 553,430 & 0.137 & 0.207 & 0.371 & 0.233 & 0.000 \\
\hline & Min & 0.010 & 0.010 & 17,297 & 0.007 & 0.034 & -0.540 & 0.000 & 6.978 \\
\hline & Max & 0.399 & 0.464 & $3,600,533$ & 0.667 & 0.819 & 1.384 & 1.000 & 6.978 \\
\hline \multirow{5}{*}{2007} & Obs & 68 & 68 & 68 & 68 & 68 & 68 & 68 & 68 \\
\hline & Mean & 0.127 & 0.171 & 599,573 & 0.177 & 0.393 & 0.292 & 0.926 & 7.130 \\
\hline & Std.Dev. & 0.060 & 0.116 & $1,056,686$ & 0.167 & 0.204 & 0.401 & 0.263 & 0.000 \\
\hline & Min & 0.015 & 0.004 & 17,602 & 0.005 & 0.048 & -0.265 & 0.000 & 7.130 \\
\hline & Max & 0.327 & 0.480 & $5,738,548$ & 0.833 & 0.899 & 2.483 & 1.000 & 7.130 \\
\hline \multirow{5}{*}{2008} & Obs & 88 & 88 & 88 & 88 & 88 & 88 & 88 & 88 \\
\hline & Mean & 0.107 & 0.173 & 582,433 & 0.115 & 0.406 & 0.225 & 0.920 & 5.662 \\
\hline & Std.Dev. & 0.084 & 0.126 & 942,291 & 0.115 & 0.222 & 0.428 & 0.272 & 0.000 \\
\hline & Min & -0.175 & 0.002 & 16,883 & 0.002 & 0.049 & -0.652 & 0.000 & 5.662 \\
\hline & Max & 0.307 & 0.586 & $5,966,959$ & 0.717 & 0.924 & 3.206 & 1.000 & 5.662 \\
\hline \multirow{5}{*}{2009} & Obs & 113 & 113 & 113 & 113 & 113 & 113 & 113 & 113 \\
\hline & Mean & 0.140 & 0.172 & 750,987 & 0.155 & 0.438 & 0.137 & 0.920 & 5.398 \\
\hline & Std.Dev. & 0.090 & 0.128 & 1,303,788 & 0.130 & 0.205 & 0.469 & 0.272 & 0.000 \\
\hline & Min & -0.063 & 0.005 & 19,956 & 0.007 & 0.073 & -0.671 & 0.000 & 5.398 \\
\hline & Max & 0.520 & 0.633 & $8,482,036$ & 0.610 & 0.894 & 3.285 & 1.000 & 5.398 \\
\hline \multirow{5}{*}{2010} & Obs & 146 & 146 & 146 & 146 & 146 & 146 & 146 & 146 \\
\hline & Mean & 0.137 & 0.183 & 871,864 & 0.141 & 0.449 & 0.258 & 0.932 & 6.423 \\
\hline & Std.Dev. & 0.083 & 0.131 & $2,122,427$ & 0.131 & 0.205 & 0.335 & 0.253 & 0.000 \\
\hline & Min & -0.075 & 0.001 & 23,655 & 0.001 & 0.065 & -0.312 & 0.000 & 6.423 \\
\hline & Max & 0.478 & 0.727 & $21,100,000$ & 0.632 & 0.922 & 1.850 & 1.000 & 6.423 \\
\hline \multirow{5}{*}{2011} & Obs & 168 & 168 & 168 & 168 & 168 & 168 & 168 & 168 \\
\hline & Mean & 0.133 & 0.191 & $1,002,825$ & 0.136 & 0.481 & 0.252 & 0.935 & 6.240 \\
\hline & Std.Dev. & 0.089 & 0.133 & 2,992,974 & 0.134 & 0.206 & 0.273 & 0.248 & 0.000 \\
\hline & Min & -0.030 & 0.004 & 19,468 & 0.001 & 0.055 & -0.388 & 0.000 & 6.240 \\
\hline & Max & 0.470 & 0.843 & $33,600,000$ & 0.546 & 0.901 & 1.202 & 1.000 & 6.240 \\
\hline \multirow{5}{*}{2012} & Obs & 171 & 171 & 171 & 171 & 171 & 171 & 171 & 171 \\
\hline & Mean & 0.115 & 0.189 & $1,103,494$ & 0.143 & 0.465 & 0.017 & 0.936 & 5.247 \\
\hline & Std.Dev. & 0.099 & 0.147 & $3,457,852$ & 0.141 & 0.211 & 0.231 & 0.246 & 0.000 \\
\hline & Min & -0.510 & 0.003 & 16,401 & 0.001 & 0.055 & -0.725 & 0.000 & 5.247 \\
\hline & Max & 0.352 & 0.902 & $38,700,000$ & 0.670 & 0.897 & 0.639 & 1.000 & 5.247 \\
\hline
\end{tabular}




\begin{tabular}{|c|c|c|c|c|c|c|c|c|c|}
\hline Year & Stat & ROA & RECA & SIZE & LQD & LEV & Sgrowth & Competiv & GDP \\
\hline \multirow{5}{*}{2013} & Obs & 173 & 173 & 173 & 173 & 173 & 173 & 173 & 173 \\
\hline & Mean & 0.110 & 0.187 & $1,252,780$ & 0.151 & 0.465 & 0.052 & 0.936 & 5.422 \\
\hline & Std.Dev. & 0.073 & 0.141 & $4,095,987$ & 0.149 & 0.204 & 0.253 & 0.245 & 0.000 \\
\hline & Min & -0.079 & 0.003 & 18,666 & 0.003 & 0.074 & -0.704 & 0.000 & 5.422 \\
\hline & Max & 0.356 & 0.826 & $46,500,000$ & 0.680 & 0.884 & 1.206 & 1.000 & 5.422 \\
\hline \multirow{5}{*}{2014} & Obs & 180 & 180 & 180 & 180 & 180 & 180 & 180 & 180 \\
\hline & Mean & 0.107 & 0.180 & $1,360,623$ & 0.149 & 0.448 & 0.125 & 0.939 & 5.984 \\
\hline & Std.Dev. & 0.067 & 0.130 & $4,523,829$ & 0.147 & 0.209 & 0.423 & 0.240 & 0.000 \\
\hline & Min & -0.026 & 0.000 & 16,204 & 0.002 & 0.025 & -0.808 & 0.000 & 5.984 \\
\hline & Max & 0.342 & 0.706 & $53,000,000$ & 0.752 & 0.932 & 4.168 & 1.000 & 5.984 \\
\hline \multirow{5}{*}{2015} & Obs & 165 & 165 & 165 & 165 & 165 & 165 & 165 & 165 \\
\hline & Mean & 0.116 & 0.177 & $1,838,123$ & 0.151 & 0.445 & 0.129 & 0.927 & 6.679 \\
\hline & Std.Dev. & 0.101 & 0.134 & $6,140,842$ & 0.141 & 0.206 & 0.378 & 0.260 & 0.000 \\
\hline & Min & -0.030 & 0.001 & 21,819 & 0.001 & 0.064 & -0.688 & 0.000 & 6.679 \\
\hline & Max & 0.988 & 0.772 & $71,800,000$ & 0.564 & 0.925 & 2.318 & 1.000 & 6.679 \\
\hline \multirow{5}{*}{2016} & Obs & 160 & 160 & 160 & 160 & 160 & 160 & 160 & 160 \\
\hline & Mean & 0.102 & 0.176 & $2,186,307$ & 0.154 & 0.443 & 0.066 & 0.925 & 6.211 \\
\hline & Std.Dev. & 0.075 & 0.144 & $6,544,656$ & 0.153 & 0.215 & 0.274 & 0.264 & 0.000 \\
\hline & Min & -0.079 & 0.001 & 21,432 & 0.000 & 0.006 & -0.767 & 0.000 & 6.211 \\
\hline & Max & 0.384 & 0.780 & $73,000,000$ & 0.656 & 0.967 & 1.139 & 1.000 & 6.211 \\
\hline \multirow{5}{*}{2017} & Obs & 168 & 168 & 168 & 168 & 168 & 168 & 168 & 168 \\
\hline & Mean & 0.085 & 0.177 & $2,375,082$ & 0.153 & 0.463 & 0.155 & 0.929 & 6.812 \\
\hline & Std.Dev. & 0.153 & 0.139 & $6,183,980$ & 0.155 & 0.208 & 0.561 & 0.258 & 0.000 \\
\hline & Min & -1.645 & 0.000 & 20,988 & 0.001 & 0.008 & -0.986 & 0.000 & 6.812 \\
\hline & Max & 0.359 & 0.771 & $63,500,000$ & 0.696 & 0.919 & 5.871 & 1.000 & 6.812 \\
\hline \multirow{5}{*}{ Total } & Obs & 1,666 & 1,666 & 1,666 & 1,666 & 1,666 & 1,666 & 1,666 & 1,666 \\
\hline & Mean & 0.116 & 0.181 & $1,317,629$ & 0.147 & 0.451 & 0.146 & 0.932 & 6.122 \\
\hline & Std.Dev. & 0.094 & 0.134 & $4,319,504$ & 0.143 & 0.208 & 0.380 & 0.253 & 0.590 \\
\hline & Min & -1.645 & 0.000 & 16,204 & 0.000 & 0.006 & -0.986 & 0.000 & 5.247 \\
\hline & Max & 0.988 & 0.902 & $73,000,000$ & 0.833 & 0.967 & 5.871 & 1.000 & 7.547 \\
\hline
\end{tabular}

Source: Own processing

\section{Variability in Trade Credit Terms Across Sub-Industries}

Tab. IV reports the variation of RECA and day sales outstanding (DSO) in proportion between manufacturing sub-industries. The first column shows the percentage of total asset value that firms use to invest in trade credit accounts. Textile mills, machinery manufacturing, plastics and rubber respectively possess $31.91 \%, 23.21 \%$ and $22.54 \%$, which are the highest values among 11 industries. Wood products, beverage-tobacco and food manufacturing, in contrast, belong to the lowest group of investing in trade credit. The second column presents an average number of days it takes a firm to collect its account receivables. Machinery manufacturing and wood products, whose DSO are about 103 days and 27 days, appear as the top and the bottom values across sub-industries. It is likely that firms which invest more in trade credit relatively have a greater number of DSO.

We examine whether there are statistical differences of RECA between sub-industries by using a one-way Analysis of Variance (ANOVA). The result is reported in Tab. IV. To ensure that we can conduct ANOVA analysis, Levene test is employed. The test is significant at the level of $1 \%$, indicating differences in variance of groups, which violates the condition to run ANOVA. Therefore, we use the Brown-Forsythe test, which has a similar function as ANOVA, to deal with this problem. The test 
III: Correlation Matrix

\begin{tabular}{|c|c|c|c|c|c|c|c|c|}
\hline & RECA & RECA2 & $\operatorname{lnSIZE}$ & LQD & Sgrowth & LEV & Competiv & GDP \\
\hline RECA & 1 & & & & & & & \\
\hline RECA2 & 0.628 & 1 & & & & & & \\
\hline lnSIZE & -0.212 & -0.044 & 1 & & & & & \\
\hline LQD & -0.320 & -0.097 & 0.030 & 1 & & & & \\
\hline Sgrowth & 0.016 & -0.051 & 0.094 & -0.032 & 1 & & & \\
\hline LEV & 0.279 & 0.140 & 0.148 & -0.384 & 0.089 & 1 & & \\
\hline Competiv & 0.014 & -0.008 & -0.294 & 0.038 & -0.035 & -0.016 & 1 & \\
\hline GDP & -0.013 & -0.025 & 0.050 & 0.017 & 0.133 & -0.016 & 0.003 & 1 \\
\hline
\end{tabular}

Source: Own processing

IV: Trade Credit Terms across Industries

\begin{tabular}{|c|c|c|c|c|}
\hline ICB & Industry & Obs & RECA (\%) & DSO \\
\hline 1730 & Wood Products & 20 & 8.51 & 26.59 \\
\hline 1750 & Furniture and Related Products & 55 & 15.53 & 67.46 \\
\hline 2720 & Plastics and Rubber & 341 & 22.54 & 59.31 \\
\hline 2730 & Machinery Manufacturing & 178 & 23.21 & 102.67 \\
\hline 2750 & Transportation Equipment Manufacturing & 17 & 16.55 & 95.30 \\
\hline 3530 & Beverage - Tobacco & 102 & 12.59 & 28.50 \\
\hline 3570 & Food Manufacturing & 411 & 14.58 & 44.72 \\
\hline 3720 & Apparel Manufacturing & 151 & 18.46 & 61.96 \\
\hline 3760 & Textile Mills & 16 & 31.91 & 64.08 \\
\hline 4530 & Miscellaneous Manufacturing & 20 & 19.49 & 53.81 \\
\hline 4570 & Chemical - Pharmaceutical & 324 & 17.49 & 54.39 \\
\hline 5550 & Printing and Related Support Activities & 31 & 14.76 & 40.72 \\
\hline \multicolumn{3}{|l|}{ ANOVA } & $13.864^{* * *}$ & $13.571^{* * *}$ \\
\hline \multicolumn{3}{|l|}{ Levene Test } & $11.458^{* * *}$ & $12.729 * * *$ \\
\hline \multicolumn{3}{|l|}{ Welch Test } & $18.545^{* * *}$ & $16.939^{* * *}$ \\
\hline \multicolumn{3}{|c|}{ Brown - Forsythe Test } & $10.729 * * *$ & $14.122^{* * *}$ \\
\hline
\end{tabular}

Source: Own processing

Note: *,* and ${ }^{* * *}$ depict significance at 10\%, 5\% and $1 \%$ level respectively

shows significance at the level of $1 \%$ and accepts the variation of trade credit investments between groups of sub-industries. The usage of the Welch test for robustness check also provides similar outcomes at the significant level of $1 \%$. We also detect statistical differences between groups when applying all procedures above for DSO. However, neither Brown-Forsythe test nor Welch test can be based on to analyse the differences between a particular group of sub-industry and the others. In this case, the Dunnett T3 post hoc test is employed.

Tab. V presents the result of the Dunnett T3 post hoc test for RECA and DSO in two panels. In panel 1, we show pairs of sub-industries having significant differences in trade credit investment. The statistics of furniture and related products, plastics and rubber, machinery manufacturing, food manufacturing, apparel manufacturing, miscellaneous manufacturing and chemical - pharmaceutical are significant and greater than wood products. Moreover, machinery manufacturing has a greater proportion of total assets that are used to expand trade receivables than beverage- tobacco, food manufacturing, apparel manufacturing, chemical - pharmaceutical and printing and related support activities. DSO analysis in the second column indicates that wood products industry has tighter credit policy than furniture and related products, plastics and rubber, machinery manufacturing, food manufacturing, apparel manufacturing and chemical - pharmaceutical; machinery manufacturing has longer period 
V: Pairwise Comparisons Results of Dunnett T3 Post Hoc Test

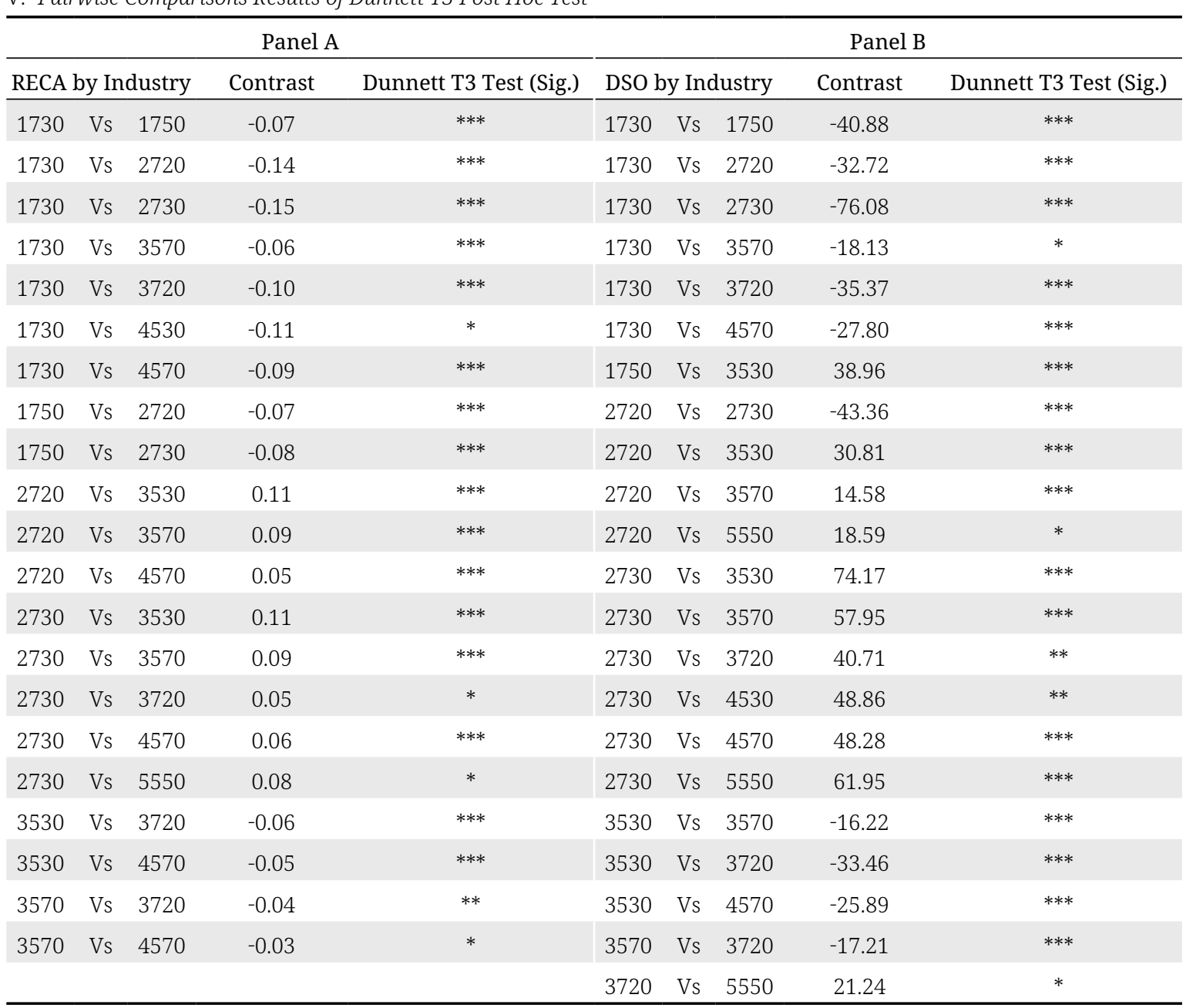

Source: Own processing

Note: ${ }^{* * *}$ and ${ }^{* * *}$ depict significance at 10\%, 5\% and $1 \%$ level respectively

of day sales outstanding when compared with beverage - tobacco, food manufacturing, apparel manufacturing, miscellaneous manufacturing, chemical - pharmaceutical and printing and related support activities. Thus, the evidence of significant variation between sub-industries has been completely provided. This finding also shares a number of similarities with Giannetti, Burkart and Ellingsen (2011) and Uyen (2012), which show heterogeneity in different industries.

\section{Trade Credit Investment and Firm Profitability}

\section{FGLS, Fixed Effects and Random Effects Estimations}

Tab. VI presents the outcomes from Wald Test (modified) and Wooldridge Test to examine the existence of heteroscedasticity and serial autocorrelation in panel data. The pro. Chi-square/F Stat of both tests are smaller than $1 \%$, showing the presence of two phenomena. Drukker (2003),
Torres-reyna (2007) and Baum (2001) introduce a method to overcome heteroscedasticity and serial autocorrelation by using clustered robust standard errors. We only apply this technique to fixed effects and random effects models since FGLS itself deals with heteroscedasticity, providing efficient estimators.

The findings of models using FGLS, fixed effects and random effects method are presented in Tab. VII. In model 1, 3, 5 we attempt to show the linear relationship between trade credit investment (RECA) and return on assets ratio. The coefficients of RECA in three models are positive and significant at the level of $1 \%, 5 \%$ and $10 \%$, respectively. In the period 2005-2017, manufacturing firms grew their profitability by taking advantage of their investments in trade credit, whose benefits not only offset the costs, but also exceed these expenditures. Estimations including quadratic terms are conducted by adding RECA2 to models and presented in models 2, 4, 6 which show negative, significant coefficients of RECA2, when 
RECA is still significant and positive. This seems to be the evidence of an inverted U-shaped relationship between trade credit investment and manufacturing firm profitability. Nevertheless, the signs of trade credit variable and its squares are necessary, but not sufficient conditions for the presence of a non-monotonic relationship (Lind and Mehlum, 2010). Lind and Mehlum (2010) also points out the weakness of regression models that only provide extreme points by estimating while monotone relationships may be found in case using relevant data not being collected. This weakness makes the conventional model not appropriate when being used to examine a decrease relationship at the left side of the interval and an increase relationship at the right side or vice versa. To clarify the presence of the U-shaped relationship, Lind and Mehlum (2010) takes advantages of likelihood ratio approach which is introduced in Sasabuchi (1980), then build a test based on the following joint null hypothesis:

HO: $\left(\beta_{1}+\beta_{2} 2\right.$ RECA $\left._{\min } \leq 0\right)$ and/or $\left(\beta_{1}+\beta_{2} 2\right.$ RECA $\left._{\max } \geq 0\right)$

against the alternative:

H1: $\left(\beta_{1}+\beta_{2} 2\right.$ RECA $\left._{\min }>0\right)$ and $\left(\beta_{1}+\beta_{2} 2\right.$ RECA $\left._{\max }<0\right)$,

where $\mathrm{RECA}_{\min }$ and $\mathrm{RECA}_{\max }$ are minimum and maximum values of the indicator of trade credit investment. If the null hypothesis is rejected, we strongly confirm that there is U-shaped relationship in the model. Begum et al. (2015), Megersa (2015) and Raff and Wagner (2012) adopt this technique, which have received the nomination SasabuchiLind-Mehlum test (SLM test), in order to attend to weaknesses in conventional models. Tab. VIII reports the result of SLM test which shows negative and significance at the level 10\% for the slope of maximum RECA in all three models 2, 4, 6, when the results for the slope of minimum RECA are also significant, but positive. The p-value of the tests in three models, which are presented in the bottom line of Tab. VIII, are all smaller than 10\%. SLM test rejects the null hypothesis (presence of inverse U-shape), showing the negative, significant effect of the quadratic term in model 2, 4, 6 .

We conduct Breusch-Pagan Lagrange Multiplier (LM) Test, F-Test and Hausman Test, respectively to select the most suitable model among FGLS, FE and RE models. The result is presented at the bottom of Tab. VII. First, we begin with Breusch-Pagan LM test to examine whether REM outperforms pooled-OLS or not. The test shows significance at the level 1\%, rejects the hypothesis that there is no existence of an individual effect, giving the reason for choosing REM instead of FGLS. F-Test, whose null hypothesis implies there is not any parameters in fixed effect model different from zero, prefers the FE model to pooled-OLS in case choosing between these two models. Since both F-Test and Breusch-Pagan LM test reject the model using FGLS, we perform the Hausman Test to choose between FE and RE models. The test rejects the hypothesis that there is no correlation between error terms and variables in the model. Finally, FE model with quadratic term (model 4) is selected and used to discuss for the remainder of this section. Based on the results, trade credit investment has the diminishing effect on firm profitability. Specifically, when manufacturing firms start to invest in trade credit, their profitability grows, but this positive effect reduces its usefulness or becomes negative as their receivables are largescale.

Liquidity, growth rate and leverage ratio are significant control variables that can be observed from model 4. Profitability of manufacturing firms which have plenty of cash and short-term investments seems to be greater than those with lower liquidity. Leverage, in contrast, has a negative effect on firm profitability. This is in complete agreement with Abor (2007), Martínez-Sola, GarcíaTeruel and Martínez-Solano (2014), and Tang (2014). Positive, significant correlation between growth rate and profitability also lends support to Martínez-Sola, García-Teruel and Martínez-Solano (2014), whose result reflects similar relationship in case of examining SMEs in Spain. Despite the fact that Martínez-Sola, García-Teruel and MartínezSolano (2014), Demsetz and Villalonga (2001) and Tang (2014) indicate that there is an increase of firm profitability when the firm size goes up, we find no significant result based on FE model.

In Tab. IX, fixed effect models with interaction terms between RECA and dummies are presented to show the effects of trade credit motives on firm profitability. This is influenced by Martínez-Sola, García-Teruel and Martínez-Solano (2014). First, we generate dummy variable SIZEDUM, which takes value 0 when firm size is smaller than the median; otherwise, it takes value 1 . This is also related to the fact that the effect of trade credit investment on profitability of manufacturing firms is expected to rise due to their abundant resources. Besides, we create LQDDUM to examine whether firms with high liquidity have better performance than those with lower liquidity. If the liquidity ratio of a firm is not smaller than the median, it takes value 1; otherwise zero. Moreover, to observe the differences among the effect of trade credit investment by industries, interaction terms between RECA and dummy variables for 11 subindustries are also employed.

Interaction terms RECAXSIZEDUM in model 1 and RECAxCompetiv in model 3 are all insignificant, indicate weak correlations between firm size and the role of Vietnamese multinational firms, respectively, and the effect of trade credit investment on profitability. Model 2 shows insignificance of LQDDUM, but a negative significance of the interaction term between RECA and LQDDUM. This finding, which shows that firms with greater liquidity obtain less profitability than those with 
VI: Heteroscedasticity and Serial Correlation Tests

\begin{tabular}{lc}
\hline \multicolumn{1}{c}{ Test } & Chi2/F Stat. \\
\hline Modified Wald Test & $23,686,733^{* * *}$ \\
Woodridge (LM) Test & $17.284^{* * *}$ \\
\hline Source: Own processing & \\
Note: *, ** and ${ }^{* * *}$ depict significance at $10 \%, 5 \%$ and \\
1\% level respectively
\end{tabular}

lower liquidity, contrast with our expectation. Model 4 shows the role of trade credit investments by sub-industries. Most of the interaction terms are significant, except for machinery manufacturing, beverage - tobacco and printing and related support activities. RECA remains significant in model 1, 2 and insignificant in model 3, 4, when its quadratic term is significant in all models. Tab. IX also indicates significance of control factors (liquidity, growth rate, leverage and GDP) in all models.

VII: FGLS, FE and RE Estimations

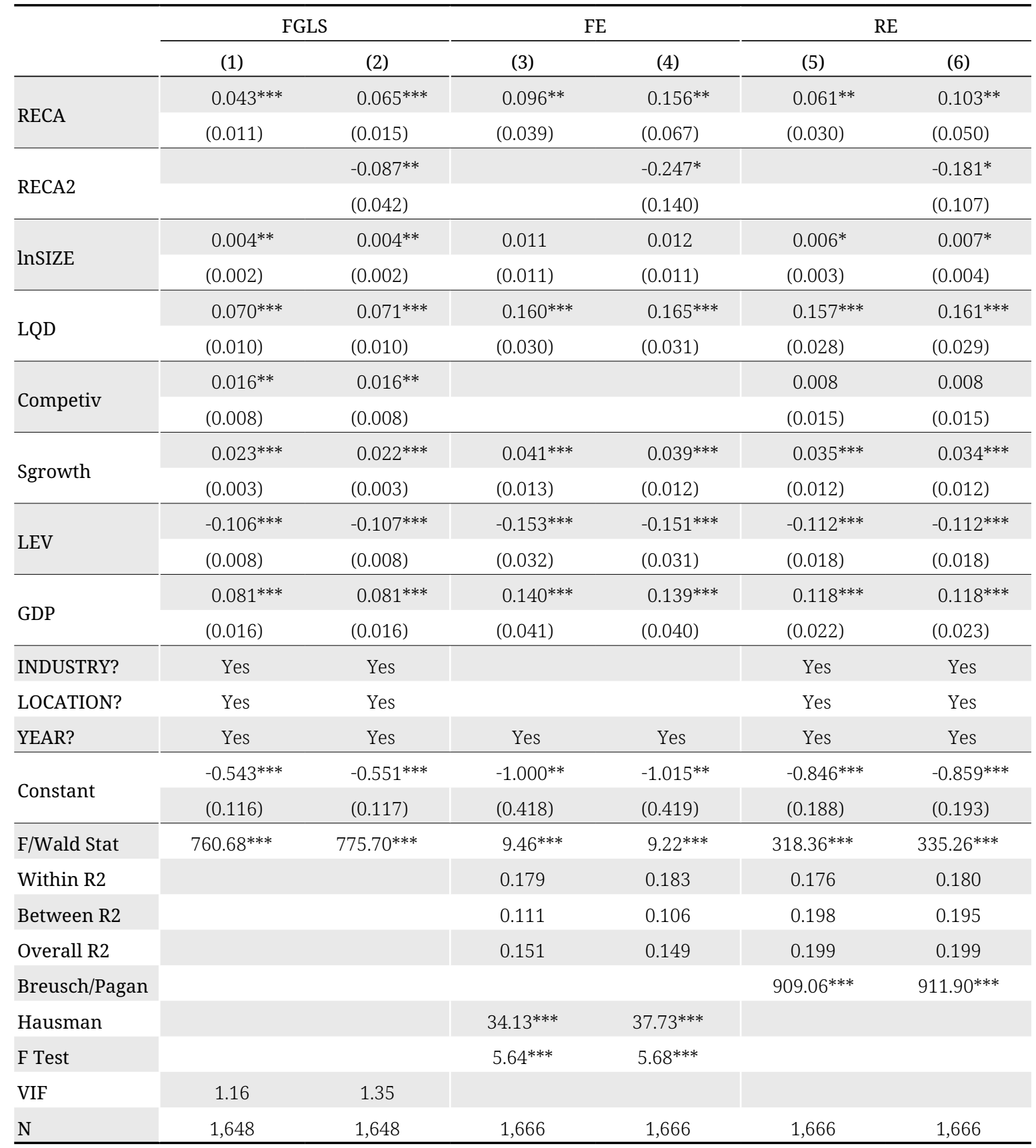

Source: Own processing

Note: The reported standard errors (in parenthesis) are cluster robust standard errors. VIF is variance inflation factor. ${ }^{*}{ }^{* *}$ and ${ }^{* * *}$ depict significance at $10 \%, 5 \%$ and $1 \%$ level respectively. 
VIII: Results of Sasabuchi-Lind-Mehlum Test for Inverse U-Shaped Relationship

\begin{tabular}{llll}
\hline & FGLS & FE & RE \\
\hline IntervalMinimum & 0 & 0 & 0 \\
IntervalMaximum & 0.902 & 0.902 & 0.902 \\
Slope at RECAMinimum & $0.064^{* * *}$ & $0.156^{* * *}$ & $0.103^{* *}$ \\
Slope at RECAMaximum & $-0.095^{*}$ & $-0.289^{*}$ & $-0.225^{*}$ \\
SLM Test for inverse U-shape & 1.37 & 1.49 & 1.50 \\
P-value & 0.086 & 0.069 & 0.067 \\
\hline
\end{tabular}

Source: Own processing

Note: *, ${ }^{* *}$ and ${ }^{* * *}$ depict significance at $10 \%, 5 \%$ and $1 \%$ level respectively

IX: FE Estimation with Interactive Terms

\begin{tabular}{|c|c|c|c|c|}
\hline & 1 & 2 & 3 & 4 \\
\hline \multirow{2}{*}{ RECA } & $0.145^{* *}$ & $0.189 * *$ & 0.132 & -0.266 \\
\hline & $(0.059)$ & $(0.076)$ & $(0.133)$ & $(0.165)$ \\
\hline \multirow{2}{*}{ RECA2 } & $-0.244^{*}$ & $-0.305^{*}$ & $-0.248^{*}$ & $-0.398 * *$ \\
\hline & $(0.138)$ & $(0.159)$ & $(0.143)$ & $(0.171)$ \\
\hline \multirow{2}{*}{$\operatorname{lnSIZE}$} & 0.012 & 0.012 & 0.012 & 0.014 \\
\hline & $(0.011)$ & $(0.011)$ & $(0.011)$ & $(0.012)$ \\
\hline \multirow{2}{*}{ LQD } & $0.165^{* * *}$ & $0.164^{* * *}$ & $0.165^{* * *}$ & $0.169 * * *$ \\
\hline & $(0.031)$ & $(0.037)$ & $(0.032)$ & $(0.031)$ \\
\hline \multirow{2}{*}{ Sgrowth } & $0.039 * * *$ & $0.040^{* * *}$ & $0.039 * * *$ & $0.039 * * *$ \\
\hline & $(0.012)$ & $(0.013)$ & $(0.012)$ & $(0.013)$ \\
\hline \multirow{2}{*}{ LEV } & $-0.151^{* * *}$ & $-0.150^{* * *}$ & $-0.151^{* * *}$ & $-0.153^{* * *}$ \\
\hline & $(0.031)$ & $(0.031)$ & $(0.031)$ & $(0.031)$ \\
\hline \multirow{2}{*}{ GDP } & $0.140^{* * *}$ & $0.139^{* * *}$ & $0.140^{* * *}$ & $0.142^{* * *}$ \\
\hline & $(0.040)$ & $(0.040)$ & $(0.041)$ & $(0.042)$ \\
\hline \multirow{2}{*}{ SIZEDUM } & -0.002 & & & \\
\hline & $(0.012)$ & & & \\
\hline \multirow{2}{*}{ RECAxSIZEDUM } & 0.025 & & & \\
\hline & $(0.050)$ & & & \\
\hline \multirow{2}{*}{ LQDDUM } & & 0.011 & & \\
\hline & & $(0.009)$ & & \\
\hline \multirow{2}{*}{ RECAxLQDDUM } & & $-0.073^{* *}$ & & \\
\hline & & $(0.037)$ & & \\
\hline \multirow{2}{*}{ RECAxCompetiv } & & & 0.026 & \\
\hline & & & $(0.142)$ & \\
\hline \multirow{2}{*}{ RECAxICB1750 } & & & & $0.495^{* *}$ \\
\hline & & & & $(0.247)$ \\
\hline \multirow{2}{*}{ RECAxICB2720 } & & & & $0.527^{* *}$ \\
\hline & & & & $(0.213)$ \\
\hline \multirow{2}{*}{ RECAxICB2730 } & & & & $0.515^{* *}$ \\
\hline & & & & $(0.203)$ \\
\hline
\end{tabular}




\begin{tabular}{|c|c|c|c|c|}
\hline & 1 & 2 & 3 & 4 \\
\hline \multirow{2}{*}{ RECAxICB2750 } & & & & 0.181 \\
\hline & & & & $(0.190)$ \\
\hline \multirow{2}{*}{ RECAxICB3530 } & & & & 0.170 \\
\hline & & & & $(0.190)$ \\
\hline \multirow{2}{*}{ RECAxICB3570 } & & & & $0.409 * *$ \\
\hline & & & & $(0.193)$ \\
\hline \multirow{2}{*}{ RECAxICB3720 } & & & & $0.456^{* *}$ \\
\hline & & & & $(0.186)$ \\
\hline \multirow{2}{*}{ RECAxICB3760 } & & & & $0.556^{*}$ \\
\hline & & & & $(0.326)$ \\
\hline \multirow{2}{*}{ RECAxICB4530 } & & & & $0.543^{* *}$ \\
\hline & & & & $(0.222)$ \\
\hline \multirow{2}{*}{ RECAxICB 4570} & & & & $0.478^{*}$ \\
\hline & & & & $(0.280)$ \\
\hline \multirow{2}{*}{ RECAxICB5550 } & & & & 0.019 \\
\hline & & & & $(0.224)$ \\
\hline Year? & Yes & Yes & Yes & Yes \\
\hline \multirow{2}{*}{ Constant } & $-1.011^{* *}$ & $-1.019 * *$ & $-1.020^{* *}$ & $-1.059 * *$ \\
\hline & $(0.419)$ & $(0.419)$ & $(0.425)$ & $(0.435)$ \\
\hline Within R2 & 0.183 & 0.186 & 0.183 & 0.192 \\
\hline F Stat & $8.5^{* * *}$ & $8.61^{* * *}$ & $8.74^{* * *}$ & $7.68^{* * *}$ \\
\hline $\mathrm{N}$ & 1,666 & 1,666 & 1,666 & 1,666 \\
\hline
\end{tabular}

Source: Own processing

Note: The reported standard errors (in parenthesis) are cluster robust standard errors. * ${ }^{* *}$ and ${ }^{* * *}$ depict significance at $10 \%, 5 \%$ and $1 \%$ level respectively

\section{Instrumental Variables (IV) Estimation}

Nadiri (1969) suggests an approach to raise profitability for firms by investing in trade credit. In fact, many firms with abundant resources have opportunities to expand credit policy since the others have been limited to do so. Thus, the effect of trade credit investment on firm profitability can be inverted, creates inconsistencies in estimation models due to endogeneity of RECA. We employ IV estimation for FE, which is also reported in Martínez-Sola, García-Teruel and Martínez-Solano (2014) and Li et al. (2016), to solve the problem of endogeneity. The procedure structured by Harding and Lamarche (2009) is adopted. We select first lagged variables RECA i,t-1 $_{\text {and }}$ RECA ${ }_{2 \mathrm{i},-1}$ as our instrumental variables following Martínez-Sola, García-Teruel and Martínez-Solano (2014), since there is inadequacy of exogenous factors for firm profitability.

Tab. X presents the result and tests related to IV FEM estimation. The first model only shows the outcome for RECA when the second one includes its square to examine U-shaped relationship. For both models, Cragg-Donald F statistics is much greater than weak ID test critical value (Stock-Yogo) at the level of 10\%. This provides evidence for using strong instruments in the model. Endogeneity test, which is insignificant in both models, reject the existence of endogeneity. Since there is not sufficient condition for an inverted U-shaped, we also employ SLM test for IV FEM estimation. In this case, lower bound is significant at the level of 1\% when upper bound is significant at the level of $5 \%$. The test points out the presence of parabolic shaped relationship between RECA and firm profitability, even more pronounced than in FE model. On the whole, IV FEM included quadratic term turns out to be the most suitable model in our paper, which indicates diminishing effect of trade credit investment on firm profitability. All control variables in the model are significant at the level of 1\%. lnSIZE, which is insignificant in the previous model, shows that larger firms have more advantages than smaller firms in improving their profitability. The sign of other variables (LQD, LEV, Sgrowth and GDP) remains the same as in the FE model. 
X: Instrumental Variable (IV) Estimation

\begin{tabular}{|c|c|c|}
\hline & 1 & 2 \\
\hline \multirow{2}{*}{ RECA } & $0.141^{* * *}$ & $0.318^{* * *}$ \\
\hline & $(0.054)$ & $(0.104)$ \\
\hline \multirow{2}{*}{ RECA2 } & & $-0.561^{* *}$ \\
\hline & & $(0.251)$ \\
\hline \multirow{2}{*}{$\operatorname{lnSIZE}$} & $0.023^{* * *}$ & $0.027^{* * *}$ \\
\hline & $(0.008)$ & $(0.009)$ \\
\hline \multirow{2}{*}{ LQD } & $0.154^{* * *}$ & $0.169^{* * *}$ \\
\hline & $(0.025)$ & $(0.026)$ \\
\hline \multirow{2}{*}{ Sgrowth } & $0.044^{* * *}$ & $0.039^{* * *}$ \\
\hline & $(0.007)$ & $(0.007)$ \\
\hline \multirow{2}{*}{ LEV } & $-0.200^{* * *}$ & $-0.197^{* * *}$ \\
\hline & $(0.024)$ & $(0.024)$ \\
\hline \multirow{2}{*}{ GDP } & $0.556^{* * *}$ & $0.540^{* * *}$ \\
\hline & $(0.150)$ & $(0.150)$ \\
\hline YEAR? & Yes & Yes \\
\hline F Stat & $4,023.94^{* * *}$ & $4,010.44^{* * *}$ \\
\hline Anderson canon. corr. LR statistic & $1,050.694^{* * *}$ & $952.281^{* * *}$ \\
\hline Cragg-Donald F statistic & $3,906.537$ & $1,405.391$ \\
\hline Hansen J statistic & 0.000 & 0.000 \\
\hline Endogeneity test of endogenous regressors & 0.018 & 0.909 \\
\hline $\mathrm{N}$ & 1,431 & 1,431 \\
\hline
\end{tabular}

Source: Own processing

Note: *** and ${ }^{* * *}$ depict significance at $10 \%, 5 \%$ and $1 \%$ level respectively

Market Based Measurement of Firm Performance

For robustness check, we consider employing an alternative for firm performance, since examining the impact of trade credit on ROA belongs to nonmarket based approach. Hall, Thoma and Torrisi (2007) and Bosworth and Rogers (2001) suggest that the stock market assesses firm value based on expectation of its activities including investments. This is also a performance indicator, but differs from ROA. Tobin's q, which is usually formed as a firm's market value to total book value, appears in Ayturk, Gurbuz and Yanik (2016); Cheng, Chan and Leung (2018) and Esqueda, Ngo and Susnjara (2019) as a measurement for firms' value in corporate finance. Other researches as Martínez-Sola, GarcíaTeruel and Martínez-Solano (2013); Dahya, Dimitrov and McConnell (2008), Saddour (2006) and Bai et al. (2004) suggest using market-to-book ratio as another proxy for Tobin's q. This alternative provides a consistent result when compared with the previous proxy. Altogether, Tobin's q is equal to market value of equity divided by book value of equity.

Tab. XI shows FE and IV FE models using Tobin's $\mathrm{q}$ as the independent variable, including RECA and its quadratic term. We also conduct an SLM test for confirming the presence of a U-shaped relationship between trade credit investment and market expectation. The outcomes for the significance of RECA, RECA2 and SLM test are consistent compared with models using ROA. When firms invest in trade credit, valuation of the market increases to maximum level, then starts to decline. This concurs well with Martínez-Sola, García-Teruel and Martínez-Solano (2013), which reveal the parabolic relationship, but lack of necessary procedures in order to ensure that reliable results are obtained. The sign of variables Sgrowth and LQD are also similar to those in estimations of previous sections. LEV is significant but positive. This can be understood as the positive correlation between discounted value of future tax saved and firm value explained in Modigliani and Miller (1963).

\section{DISCUSSION}

Those empirical results presented above not only express the relationship between trade credit investment and firms' performance quantitatively but also provide us the answer for economic phenomena existing in Vietnammese manufacturing industry. 
XI: Results of Trade Credit and Firm Value Estimations

\begin{tabular}{|c|c|c|}
\hline & $\mathrm{FE}$ & FE IV \\
\hline \multirow{2}{*}{ RECA } & $0.790^{* *}$ & $1.981^{* *}$ \\
\hline & $(0.364)$ & $(0.995)$ \\
\hline \multirow{2}{*}{ RECA2 } & $-2.137^{* *}$ & $-5.720^{* *}$ \\
\hline & (0.999) & (2.392) \\
\hline \multirow{2}{*}{$\operatorname{lnSIZE}$} & $-0.180^{* * *}$ & -0.052 \\
\hline & $(0.068)$ & $(0.082)$ \\
\hline \multirow{2}{*}{ LQD } & $1.004^{* * *}$ & $1.042^{* * *}$ \\
\hline & (0.219) & $(0.251)$ \\
\hline \multirow{2}{*}{ Sgrowth } & $0.097^{*}$ & 0.007 \\
\hline & (0.059) & $(0.070)$ \\
\hline \multirow{2}{*}{ LEV } & $1.419 * * *$ & $1.280^{* * *}$ \\
\hline & $(0.205)$ & $(0.228)$ \\
\hline \multirow{2}{*}{ GDP } & 0.053 & $8.818^{* * *}$ \\
\hline & (0.334) & (1.431) \\
\hline YEAR? & Yes & Yes \\
\hline \multirow{2}{*}{ Constant } & 2.662 & $-58.80^{* * *}$ \\
\hline & (2.825) & (10.30) \\
\hline Rho & 0.697 & 0.730 \\
\hline F Stat/Wald & $83.07^{* * *}$ & $6,133 \cdot 19^{* * *}$ \\
\hline Within R2 & 0.513 & 0.416 \\
\hline Between R2 & 0.005 & 0.001 \\
\hline Overall R2 & 0.197 & 0.145 \\
\hline $\mathrm{N}$ & 1,666 & 1,431 \\
\hline
\end{tabular}

Firstly, in view of descriptive statistics, we can observe that a firm spends more than 18\% of its total assets for trade credit investment, on average. This value seems to be low relative to European SMEs. Asimakopoulos, Da and Fernandes (2017) reports that European firms engage in providing and receiving trade credit at the levels of 33.4\% and $21.4 \%$ respectively, as a share of their assets. Due to the development in scale and expertise compared to Vietnamese enterprises, European SMEs have capability to optimize the use of trade credit so as to promote their profitability. In contrast, most Vietnamese manufacturing firms are lacking in qualification for managing trade credit strategy. Indeed, assessing 2019 working capital performance of Vietnamese enterprises, PwC reported that ROCE declined 6.7 percentage points because of deterioration in cash conversion and the working capital cycle increased by 2 days owing to an inefficient receivables and inventory management. Moreover, according to Fig. 1, we also find that the level of trade credit has fluctuated during history. In the period of 2007-2008, firms seemed to tighten the credit policies that resulted in decreasing the value of RECA to $17.2 \%$. On the other hand, when the economy is stable, firms are willing to loosen their credit strategy. This finding is in line with the result of Kestens, Van Cauwenberge and Bauwhede (2012) and supports the idea of Afrifa and Gyapong (2017) that conclude financial recession has a negative impact on the trade credit supply.

Secondly, the trade credit policies are likely to be varying among manufacturing industries. In the section of results, we have presented that firms which produce textile mills, machinery, plastic and rubber products have the highest value of RECA while firms manufacturing wood products, beverages - tobacco and foods seem to apply the tightest credit policies. This is appropriate to the characteristics of different types of products. Firms with perishable types of products such as beverage and food do not want to expand credit for their customers. For this reason, the DSOs of these firms are quite low. Although wood products are not 


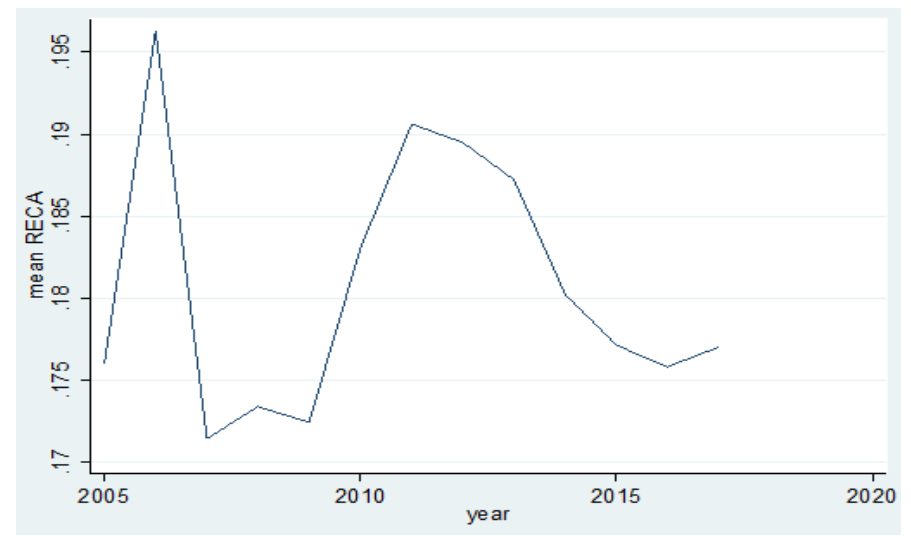

1: Trend of mean RECA

Source: Own processing

perishable, the scale of these firms is small with low qualified workforce. The workforce in the wood manufacture industry consists of 300,000 workers, only $10 \%$ of them graduated from university. In addition to the lack of professionals, the standard of business administration in this industry is not high. These factors create difficulties for wood manufacturing firms in expanding their trade credit policies. Contrary to lowest RECA firms, firms with highest RECA are experts in manufacturing durable products. Textile mills, machinery or plastic rubber are also leading industries in Vietnam. Therefore, these firms are not only large in scale but also professional in management. Thanks to the high standard of operation and characteristics of their product, these firms are willing to allow their buyer to delay in payment. As a result, DSOs of these firms are also on the highest top. These reasons may explain why firms which invest more in trade credit relatively have a greater number of DSOs.

Thirdly, we discover that there is a nonlinear relationship between trade credit investment and Vietnamese manufacturing firms' profitability. Particularly, if firms apply reasonable levels of trade credit, they can improve their performance and increase their profits. Moreover, they are able to maximize their profits in case they optimize their trade credit investment strategy. However, their profits will invert when the value of RECA exceeds an extreme point. These findings fit theories which we mentioned above. It is said that if benefits exceed costs arising from trade credit investment, firm's profits will increase and vice versa. By supplying trade credit for customers, firms are beneficial from the reduction of transaction costs, storage costs and the increase in sales while costs of investment in trade credit arising from administration and financial risks. The abuse of trade credit may lead to bankruptcy of a company. Jacobson and von Schedvin (2015) find that debtor failures are associated with substantially enhanced bankruptcy risks for the trade creditors. More than 98\% of Vietnamese firms are small and medium and $70 \%$ of them are short of capital as they hardly access to receive credit support from banks. Hence, Vietnamese enterprises in general and Vietnamese manufacturing firms in particular seem to be more probable in bankruptcy when their trade debtors default. Our results also lend support to previous findings of Asimakopoulos, Da and Fernandes (2017) which points out the existence of a nonmonotonic "U-shaped" relationship between net trade credit and firm performance in European SMEs.

In brief, our paper has provided answers for the phenomenon of the relationship between trade credit investment and the performance of manufacturing firms in Vietnam. Nonetheless, it still contains several limitations. First of all, as discussed above, there are significant differences among different manufacturing industries and so further works of similar topics should concentrate on more specific industries. This can help firms develop particular strategies in supplying credit. Next, we use data collected from the stock exchange of Vietnam. Hence, firms in our sample are listed companies. This means that there are still a huge number of non-listed companies that are not included in our research. Additionally, these two types of firms have numerous significant differences. Then, future researchers should collect data from both listed and non-listed companies to examine the difference between them in trade credit policies. Despite limitations above, this article has presented essential materials for studying in the field of trade credit in Vietnam. 


\section{CONCLUSION}

In this study, we have concerned the impact that trade credit has on firm profitability using the data of more than 1,600 samples collecting from manufacturing firms in Vietnam. We employ FGLS, fixed effect and random effect model to test both linear and U-shape relationship then combine Lind and Mehlum (2010) method so as to confirm the presence of the U-shaped relationship. FE model was chosen as the most suitable model through LM Test, F-Test and Hausman Test. This finding has been strengthened later in the examination of endogeneity using Instrumental Variables Estimation which points out the presence of parabolic shaped relationship between RECA and firm profitability, even more pronounced in IV FE model. For robustness check, we consider employing Tobin'q as a market-based measurer for firm performance. The result is consistent with that when using ROA. Our finding is robust to vary econometric methods and models with different measurers of firm profitability. Hence, we can conclude that trade credit does affect manufacturing firm performance in a U-shaped form.

Our work does not only contribute a solid proof for the parabolic relationship of trade credit and performance of firms but also play an important role as a guideline for policy managers. The revenue can be increased by investing in trade credit attributing to financing, transaction cost and commercial theory. However, the policymakers now should consider the maximum level of credit that they can offer since after that point, the effect will be converted. This suggestion is applicable for those countries having the economy mostly including SMEs as Vietnam.

\section{Acknowledgements}

This research is funded by University of Economics Ho Chi Minh City, Vietnam.

We are grateful to the two anonymous peer reviewers for their constructive comments.

\section{REFERENCES}

ABOR, J. 2007. Debt policy and performance of SMEs: Evidence from Ghanaian and South African firms. Journal of Risk Finance, 8(4): 364-379.

ABUHOMMOUS, A. A. A. 2017. The Impact of Offering Trade Credit on Firms' Profitability. Journal of Corporate Accounting \& Finance, 28(6): 29-40.

AFRIFA, G. A. 2016. Net working capital, cash flow and performance of UK SMEs. Review of Accounting and Finance, 15(1): 21-44.

AFRIFA, G. A. and GYAPONG, E. 2017. Net trade credit: what are the determinants? International Journal of Managerial Finance, 13(3): 246-266.

ALARCÓN, S. 2011. The trade credit in the Spanish agro-food industry. New Medit, 10(2): 51-57.

ASIMAKOPOULOS, S., FERNANDES, F. D. S. and KARAVIAS, Y. 2017. Net Trade Credit and Firm Performance. Available at: https://editorialexpress.com/cgi-bin/conference/download.cgi?db_ name=IAAE2018\&paper_id=122 [Accessed: 2020, July 15].

AYTURK, Y., GURBUZ, A. O. and YANIK, S. 2016. Corporate derivatives use and firm value: Evidence from Turkey. Borsa Istanbul Review, 16(2):108-120.

BAI, C. E., LIU, Q., LU, J. et al. 2004. Corporate governance and market valuation in China. Journal of Comparative Economics, 32(4): 599-616.

BAUM, C. F. 2001. Residual Diagnostics for Cross-section Time Series Regression Models. The Stata Journal: Promoting communications on statistics and Stata, 1(1): 101-104.

BEGUM, R. A., SOHAG, K., ABDULLAH, S. et al. 2015. CO2 emissions, energy consumption, economic and population growth in Malaysia. Renewable and Sustainable Energy Reviews, 41: 594-601.

BOSWORTH, D. and ROGERS, M. 2001. Market value, R\&D and intellectual property: An empirical analysis of large Australian firms. Economic Record, 77(239): 323-337.

BOX, T., DAVIS, R., HILL, M. et al. 2018. Operating performance and aggressive trade credit policies. Journal of Banking \& Finance, 89: 192-208.

DE CARVALHO, C. J. and SCHIOZER, R. F. 2015. Determinants of supply and demand for trade credit by micro, small and medium-sized enterprises. Revista Contabilidade e Financas, 26(68): 208-222.

CHEN, C. and KIESCHNICK, R. 2018. Bank credit and corporate working capital management. Journal of Corporate Finance, 48: 579-596.

CHENG, L. T. W., CHAN, R. Y. K. and LEUNG, T. Y. 2018. Impact of perk expenditures and marketing expenditures on corporate performance in China: The moderating role of political connections. Journal of Business Research, 86: 83-95.

CHENG, N. S. and PIKE, R. 2003. The trade credit decision: Evidence of UK firms. Managerial and Decision Economics, 24(6-7): 419-438. 
DAHYA, J., DIMITROV, O. and MCCONNELL, J. J. 2008. Dominant shareholders, corporate boards, and corporate value: A cross-country analysis. Journal of Financial Economics, 87(1): 73-100.

DARY, S. K. and JAMES, H. S. 2019. Does investment in trade credit matter for profitability? Evidence from publicly listed agro-food firms. Research in International Business and Finance, 47: 237-250.

DELOOF, M. 2003. Does working capital management affect profitability of Belgian firms? Journal of Business Finance and Accounting, 30(3-4): 573-587.

DELOOF, M. and JEGERS, M. 1999. Trade credit, corporate groups, and the financing of Belgian firms. Journal of Business Finance and Accounting, 26(7-8): 945-966.

DEMIRGUC-KUNT, A. and MAKSIMOVIC, V. 2001. Firms as Financial Intermediaries: Evidence from trade credit data. Policy, Research working paper No. WPS 2696. Washington, D.C.: World Bank Group.

DEMSETZ, H. and VILLALONGA, B. 2001. Ownership structure and corporate performance. Journal of Corporate Finance, 7(3): 209-233.

DHOLE, S., MISHRA, S. and PAL, A. M. 2019. Efficient working capital management, financial constraints and firm value: A text-based analysis. Pacific-Basin Finance Journal, 58: 101212.

DRUKKER, D. M. 2003. Testing for Serial Correlation in Linear Panel-data Models. The Stata Journal: Promoting communications on statistics and Stata, 3(2): 168-177.

EMERY, G. W. 1984. A Pure Financial Explanation for Trade Credit. The Journal of Financial and Quantitative Analysis, 19(3): 271-285.

ESQUEDA, O. A., NGO, T. and SUSNJARA, J. 2019. The effect of government contracts on corporate valuation. Journal of Banking \& Finance, 106: 305-322.

FAFCHAMPS, M., PENDER, J. and ROBINSON, E. 1995. Enterprise finance in Zimbabwe. RPED Case Study Series. Washington DC: World Bank.

FERRIS, J. S. 1981. A Transactions Theory of Trade Credit Use. The Quarterly Journal of Economics, 96(2): 243-270.

GIANNETTI, M., BURKART, M. and ELLINGSEN, T. 2011. What you sell is what you lend? Explaining trade credit contracts. Review of Financial Studies, 24(4): 1261-1298.

GODDARD, J., TAVAKOLI, M. and WILSON, J. O. S. 2005. Determinants of profitability in European manufacturing and services: Evidence from a dynamic panel model. Applied Financial Economics, 15(18): 1269-1282.

GOFMAN, M. 2013. Profitability, Trade Credit and Institutional Structure of Production. SSRN. [Online]. Available at: https://ssrn.com/abstract=2365995. [Accessed: 2013, December 9].

GRAU, A. J. and REIG, A. 2018. Trade credit and determinants of profitability in Europe. The case of the agri-food industry. International business review, 27(5): 947-957.

Greene, W. H. 2002. Econometric Analysis. $5^{\text {th }}$ Edition. New York: Prentice Hall.

HAIR, J. F., BLACK, W. C., BABIN, B. J. et al. 1995. Multivariate Data Analysis. $3^{\text {rd }}$ Edition. New York: Macmillan Publishing Company.

HALL, B. H., THOMA, G. and TORRISI, S. 2007. The market value of patents and R\& D: Evidence from european firms. In: Academy of Management 2007 Annual Meeting: Doing Well by Doing Good. AOM 2007.

HARDING, M. and LAMARCHE, C. 2009. A quantile regression approach for estimating panel data models using instrumental variables. Economics Letters, 104(3): 133-135.

JACOBSON, T. and VON SCHEDVIN, E. 2015. Trade Credit and the Propagation of Corporate Failure: An Empirical Analysis. Econometrica, 83(4): 1315-1371.

JĘDRZEJCZAK-GAS, J. 2017. Net Working Capital Management Strategies in the Construction Enterprises Listed on the NewConnect Market. Procedia Engineering, 182: 306-313.

JORDAN, J., LOWE, J. and TAYLOR, P. 1998. Strategy and financial policy in UK small firms. Journal of Business Finance and Accounting, 25(1-2): 1-27.

KESTENS, K., VAN CAUWENBERGE, P. and BAUWHEDE, H. V. 2012. Trade credit and company performance during the 2008 financial crisis. Accounting and Finance, 52(4): 1125-1151.

KIM, W. S. 2016. Determinants of corporate trade credit: An empirical study on Korean firms. International Journal of Economics and Financial Issues, 6(2): 414-419.

LI, D., LU, Y., NG, T. et al. 2016. Does trade credit boost firm performance? Economic Development and Cultural Change, 64(3): 573-602.

LIND, J. T. and MEHLUM, H. 2010. With or without u? the appropriate test for a U-shaped relationship. Oxford Bulletin of Economics and Statistics, 72(1): 109-118.

LONG, S., MALITZ, I. B. and RAVID, S. A. 1993. Trade credit, quality guarantees, and product marketability. Financial Management Association International, 22(4): 117-127.

LORENZ, M. B. 2014. The Relation between Trade Credit Structures and Firm- and Supply Chain Profitability. Masters' Thesis. Copenhagen Business School. 
MARTÍNEZ-SOLA, C., GARCÍA-TERUEL, P. J. and MARTÍNEZ-SOLANO, P. 2013. Trade credit policy and firm value. Accounting and Finance, 53(3): 791-808.

MARTÍNEZ-SOLA, C., GARCÍA-TERUEL, P. J. and MARTÍNEZ-SOLANO, P. 2014. Corporate cash holding and firm value. Applied Economics, 45(2): 161-170.

MAURY, B. 2006. Family ownership and firm performance: Empirical evidence from Western European corporations. Journal of Corporate Finance, 12(2): 321-341.

MCGUINNESS, G., HOGAN, T. and POWELL, R. 2018. European trade credit use and SME survival. Journal of Corporate Finance, 49: 81-103.

MEGERSA, K. A. 2015. The laffer curve and the debt-growth link in low-income Sub-Saharan African economies. Journal of Economic Studies, 42(5): 878-892.

MELTZER, A. H. 1960. Mercantile Credit, Monetary Policy, and Size of Firms. The Review of Economics and Statistics, 42(4): 429-437.

MODIGLIANI, F. and MILLER, M. H. 1963. Corporate income taxes and the cost of capital: a correction. The American Economic Review, 433-443.

MUN, S. G. and JANG, S. 2015. Working capital, cash holding, and profitability of restaurant firms. International Journal of Hospitality Management, 48: 1-11.

MUSCETTOLA, M. 2014. Cash Conversion Cycle and Firm's Profitability: An Empirical Analysis on a Sample of 4,226 Manufacturing SMEs of Italy. International Journal of Business and Management, 9(5): 25-35.

MUTHAMA MUSAU, V., WAITITU, A. G. and WANJOYA, A. K. 2015. Modeling Panel Data: Comparison of GLS Estimation and Robust Covariance Matrix Estimation. American Journal of Theoretical and Applied Statistics, 4(3): 185-191.

NADIRI, M. I. 1969. The Determinants of Trade Credit in the U.S. Total Manufacturing Sector. Econometrica, 37(3): 408.

NG, C. K., SMITH, J. K. and SMITH, R. L. 1999. Evidence on the determinants of credit terms used in interfirm trade. Journal of Finance, 54(3): 1109-1129.

NGUYEN, T. M., TRAN, T. Q. and DO, L. T. 2018. Government Support and Firm Profitability in Vietnam. Comparative Economic Research, 21(4): 105-120.

PAUL, S. Y., DEVI, S. S. and TEH, C. G. 2012. Impact of late payment on Firms' profitability: Empirical evidence from Malaysia. Pacific-Basin Finance Journal, 20(5): 777-792.

PIRTTILÄ, M., VIROLAINEN, V., LIND, L. et al. 2019. Working capital management in the Russian automotive industry supply chain. International Journal of Production Economics, 221(C): 107474.

RAFF, H. and WAGNER, J. 2012. Productivity and the product scope of multi-product firms: A test of Feenstra-Ma. Working Paper Series in Economics No. 257. University of Lüneburg.

LA ROCCA, M., LA ROCCA, T. and CARIOLA, A. 2010. The influence of local institutional differences on the capital structure of SMEs: Evidence from Italy. International Small Business Journal, 28(3): 234-257.

SADDOUR, K. 2006. The Determinants and the Value of Cash Holdings: Evidence from French firms. Cahier de Recherche CEREG, 6: 1-33.

SASABUCHI, S. 1980. A test of a multivariate inequalities by linear determined by linear inequalities. Biometrika, 67(2): 429-439.

SCHWARTZ, R. A. 1974. An Economic Model of Trade Credit. The Journal of Financial and Quantitative Analysis, 9(4): 643-657.

SMITH, J. K. 1987. Trade Credit and Informational Asymmetry. The Journal of Finance, 42(4): 863-872.

TANG, Y. 2014. Trade Credit and Profitability in Small and Medium Enterprises. Essay. University of Twente, Behavioural, Management and Social Sciences.

TORRES-REYNA, O. 2007. Panel Data Analysis Fixed and Random Effects longitudinal or cross-is a dataset in which the behavior of entities are observed across time. Available at: http://www.princeton. edu/ otorres/Panel101.pdf [Accessed: 2007, December].

TRAN, H., ABBOTT, M. and JIN YAP, C. 2017. How does working capital management affect the profitability of Vietnamese small and medium sized enterprises? Journal of Small Business and Enterprise Development, 24(1): 2-11.

TSURUTA, D. 2015. Leverage and firm performance of small businesses: evidence from Japan. Small Business Economics, 44(2): 385-410.

UYEN, N. L. T. 2012. Trade Credit in the Rice Market of the Mekong Delta in Vietnam. PhD Thesis. University of Groningen.

VU, T.-H., NGUYEN, V., HO, M. et al. 2019. Determinants of Vietnamese Listed Firm Performance: Competition, Wage, CEO, Firm Size, Age, and International Trade. Journal of Risk and Financial Management, 12(2): 62. 
VAN DER WIJST, N. and THURIK, R. 1993. Determinants of small firm debt ratios: An analysis of retail panel data. Small Business Economics, 5(1): 55-65.

WILNER, B. S. 2000. The exploitation of relationships in financial distress: The case of trade credit. Journal of Finance, 55(1): 153-178.

WOOLDRIDGE, J. M. 2010. Econometric Analysis of Cross Section and Panel Data. $2^{\text {nd }}$ Edition. London: The MIT Press.

WOOLDRIDGE, J. M. 2016. Introductory Econometrics. $6^{\text {th }}$ Edition. Michigan: Cengage Learning.

ZHU, J. and JIANG, G. 2009. Trade Credit, Future Earnings, and Stock Returns: A Self-Dealing Perspective. China Journal of Accounting Research, 2(2): 59-79.

Contact information

Duong Phuong Thao Pham: pdpthao@ueh.edu.vn

Thi Cam Ha Huynh: hatcdn@ueh.edu.vn 